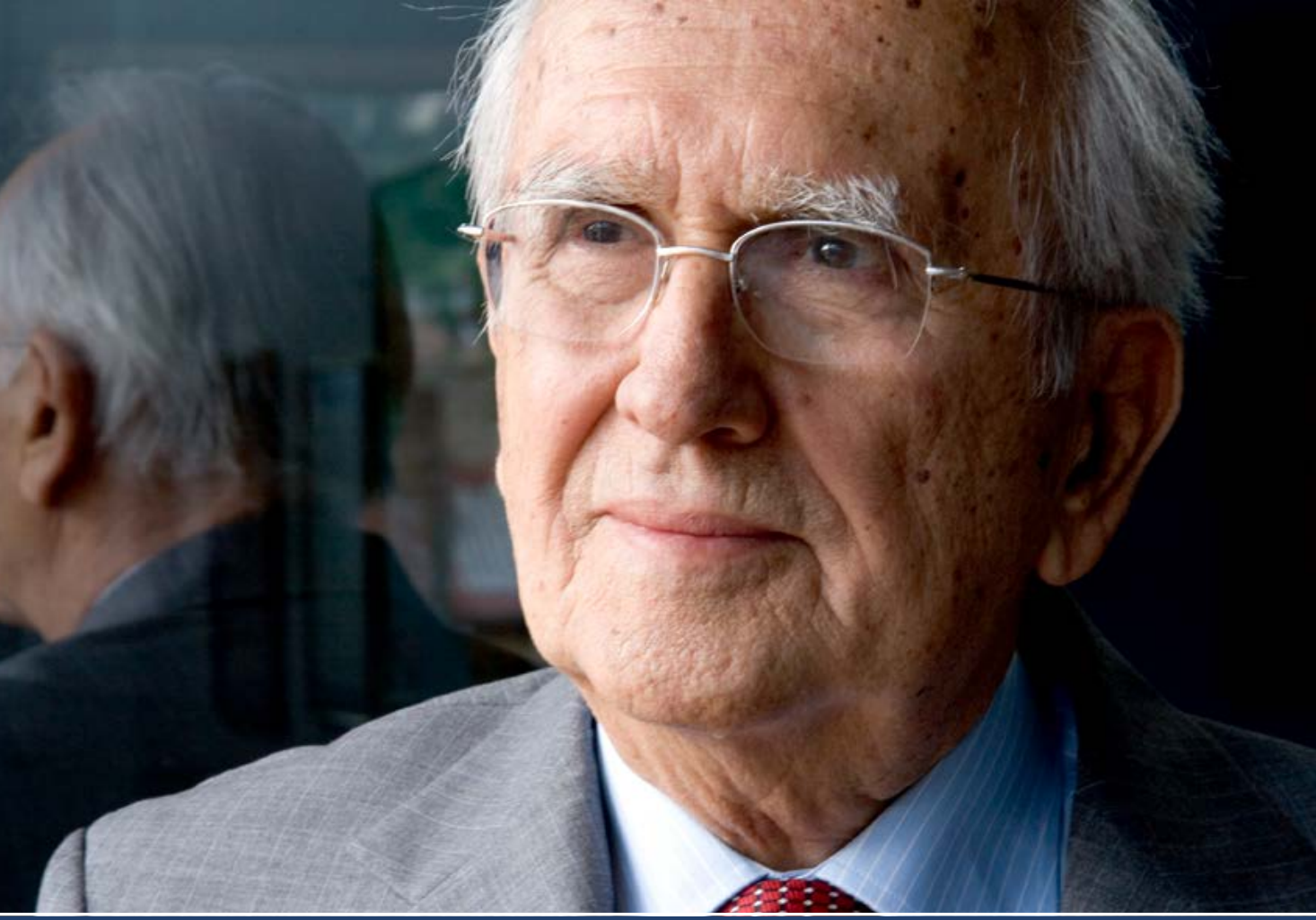

\title{
Građanski i komunistički liberali u Srbiji o Bosni i Hercegovini
}

Dr. sc. Milivoj Bešlin

109-128.

Adil Zulfikarpašić i liberalne političke inicijative ZBORNIK RADOVA 



\title{
Građanski i komunistički liberali u Srbiji o Bosni i Hercegovini ${ }^{1}$
}

\author{
Dr. sc. Milivoj Bešlin
}

Institut za filozofiju i društvenu teoriju Univerziteta u Beogradu milivoj.beslin@gmail.com

SAžETAK: Rad polazi od toga da je u teritorijalnim aspiracijama srpskog nacionalizma u 19. i 20. veku Bosna i Hercegovina bila u središtu ekspanzije. Nasuprot dominantnim tendencijama nacionalističke matrice, manjinska liberalna alternativa u Srbiji, iako i sama deo tzv. velikog (nacionalnog) narativa, pokazivala je znatno više senzibiliteta za različitosti $\mathrm{BiH}$, iskazujući potrebu da se ona utemelji kao zasebna jedinica u jugoslovenskom federalizmu. Ipak, kada je socijalistička vlast u Titovoj Jugoslaviji omogućila državnost i suštinsku ravnopravnost Bosne i Hercegovine, većina liberalnih intelektualaca je iskazivala nezadovoljstvo takvom konste- lacijom. Bosanskohercegovačka državnost je, kao i njene granice, doživljavana kao privremena i provizorna. Jedina politička struktura u Srbiji koja je pokazivala puno razumevanje za suštinsku državnost $\mathrm{BiH}$ i koja je načinila potpuni diskontinuitet sa stavovima srpskih elita prema Bosni i Hercegovini bili su komunistički liberali, reformsko rukovodstvo Marka Nikezića u Srbiji krajem 1960-ih i početkom 1970-ih godina.

KLJUČNE REČI: Jugoslavija, Srbija, Bosna i Hercegovina, nacionalizam, građanski liberali, komunistički liberali, federalizam.

\section{Bosna i Hercegovina kao središte velikodržavne ideje srpskog nacionalizma}

Bosna i Hercegovina od 19. veka predstavlja jezgro i središni deo teritorijalnih pretenzija velikodržavne ideologije srpskog nacionalizma. Od prvih nacionalnih liberala, koji su Bosnu i Hercegovinu smatrali srpskom zemljom, do Berlinskog kongresa (1878) Srbija je svoju pretenziju usmeravala ka zapadu. Međunarodno priznanje nezavisnosti i teritorijalno proširenje, dobijeno na Kongresu, dočekani su s velikim nezadovoljstvom 
i interpretirani kao neuspeh, jer je s autoritetom konsenzualnosti velikih sila sankcionisan austrougarski otpor stvaranju znatno proširene srpske države. ${ }^{2}$ Odluke Kongresa činile su se kao konačni slom velikodržavne ideje, tim pre što su ustupci učinjeni Srbiji, na zalaganje Beča, morali biti plaćeni odustajanjem od teritorijalnih pretenzija na zapad, tj. teritoriju Bosne i Hercegovine, koju je Monarhija smatrala svojom interesnom zonom, stavljajući je pod privremenu upravu. ${ }^{3}$ Nacionalistička ekspanzija mogla je biti usmerena ka jugu, u pravcu Osmanskog carstva, zapravo Kosova i Makedonije, gde su neskrivene pretenzije iskazivali bugarski i grčki susedi.

U tom kontekstu, dalji razvoj nezavisne srpske države nakon 1878. godine bio je opterećen dugoročnom istorijskom kontroverzom: razvoj realne države i njena modernizacija po ugledu na napredna zapadnoevropska društva, što je podrazumevalo makar privremeno odustajanje od temeljnih vrednosti i ciljeva nacionalističke, ekspanzivne ideje ili fokusiranje na teritorijalnu ekspanziju s ciljem stvaranja svesrpske države radi ostvarenja zavetnih ciljeva u kojima je Bosna i Hercegovina imala središnju ulogu. Reč je o permanentnom disputu dve istorijske tendencije: konzervativne i liberalne. ${ }^{4}$ Ipak, od 1878. i Berlinskog kongresa Srbija je retka država koja ne samo da ne obeležava dan kada je dobila međunarodno priznanje (i teritorijalno proširenje) već ga je tumačila kao nacionalnu tragediju zbog toga što nije dobila međunarodno odobrenje da zauzme Bosnu i Hercegovinu. U tom kontekstu, tzv. aneksiona kriza 1908. biće čitav vek intepretirana $u$ istoriografiji kao jedan od najtraumatičnijih perioda srpske istorije. Preludijum epohe ratova na Balkanu bila je upravo aneksiona kriza 1908/09. inicirana unilateralnim aktom Austro-Ugarske da Bosnu i Hercegovinu, koju je držala pod okupacijom, trajno pripoji, tj. anektira. ${ }^{5}$ Nakon objave ove odluke javno mnjenje Srbije i svi politički činioci proključali su. Izazvan odlukom dvorskih krugova u Beču, srpski nacionalizam je prvi put spontano i sa ogromnom mobilizacijskom snagom izašao na scenu, u javni prostor. Protestne povorke pripadnika homogenizovane nacije ispunile su beogradske ulice, tražila se objava rata moćnom severnom

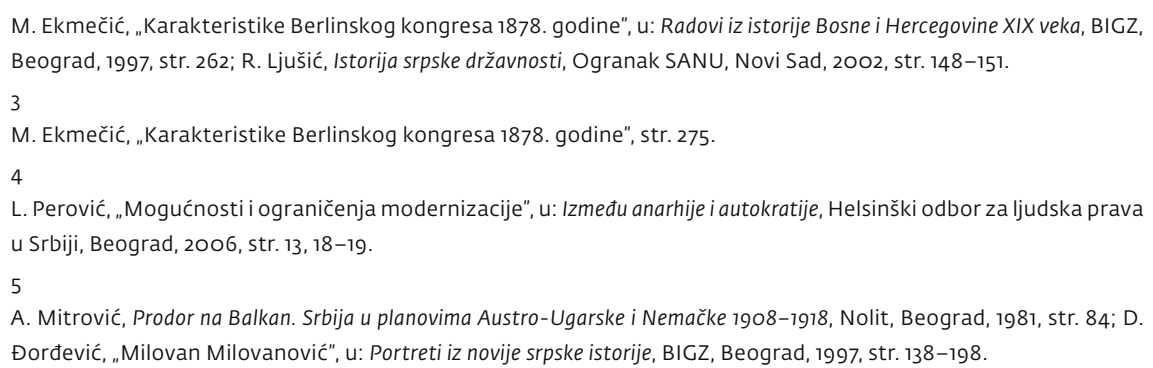


susedu, čije su zastave spaljivane širom zemlje. Austrougarski poslanik u Beogradu je, opisujući stanje u srpskoj prestonici, svojoj vladi napisao: „Svi su spremni da ginu." ${ }^{\circ} \mathrm{U}$ jeku tzv. aneksione krize, oktobra 1908. formirana je nacionalistička organizacija Narodna odbrana s ciljem „negovanja osećaja o celini srpske nacije”, kao i sa težnjom da se „ujedine sve nacionalne snage i obrazuju dobrovoljačke jedinice za predstojeći rat”. Za kratko vreme organizacija je premrežila Srbiju svojim lokalnim odborima, upisujući hiljade dobrovoljaca.7 Vernakularizovani srpski nacionalizam stupio je na istorijsku pozornicu Jugoistočne Evrope i neće se sa nje povući čitav naredni vek.

\section{Rodonačelnik srpskog liberalizma i Bosna i Hercegovina kao „srpska zemlja”}

U 19. veku nacionalizam je kao emancipatorski pokret često bio u sinkretizmu s liberalizmom, a individualne slobode su povezivane s kolektivnim, nacionalnim oslobođenjem. Međutim, kako je nacionalizam kao ideologija postajao oruđe u rukama najširih političkih struktura, sve više su ga preuzimali konzervativni i reakcionarni političari, usled čega se fanatizovao i dolazio do svoje krajnje ishodišne tačke u 20. veku - fašizma. Nacionalistička težnja više nije išla za idejama političke slobode i demokratije, već je glorifikovala imaginativnu nacionalnu slavu i vojne pobede iz prošlosti, a „takav nacionalizam je sve više postajao šovinistički i ksenofobičan”. Svaka nacija je vlastite kvalitete smatrala nadmoćnim i superiornim, dok su druge nacije tretirane kao tuđe, neprijateljske i preteće. ${ }^{8} \mathrm{U}$ skladu s tim, teoretičari su uočili „šizofreni politički karakter nacionalizma” kao ideologije i doktrine koja je mogla biti, zavisno od konteksta, i progresivna i reakcionarna, demokratska i autoritarna, racionalna i iracionalna, levičarska i desničarska. Uz to, nacionalizam je bio povezan sa svim ključnim ideološkim tradicijama evropske političke misli: bio je privlačan za liberale, konzervativce, socijaliste, fašiste, čak i komuniste. Možda je samo anarhizam, zbog otvorenog negiranja države, ostao do kraja u suštinskom i trajnom nesaglasju s nacionalizmom. ${ }^{9}$

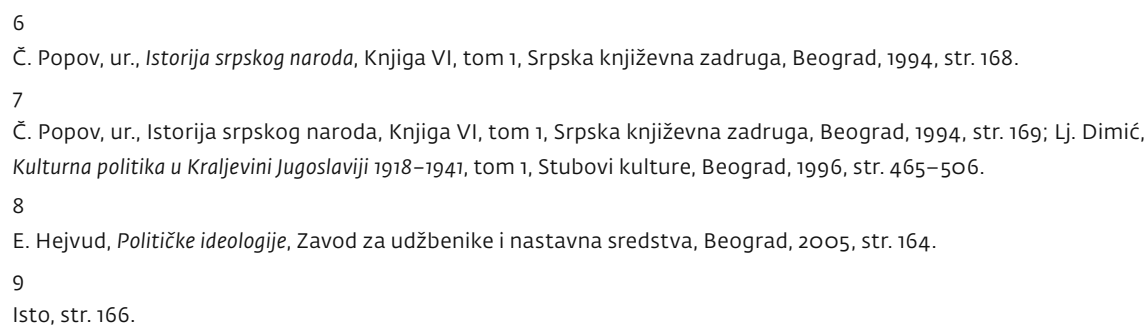


U tom kontekstu posmatrano, srpski liberalizam je preko svoga utemeljitelja i ključnog teoretičara i diseminatora Vladimira Jovanovića bio od početka u simbiotičkoj vezi s nacionalizmom. U središtu nacionalističkih težnji bilo je uključivanje Bosne i Hercegovine u državni sastav Srbije i amalgamisanje njenih stanovnika u Srbe, identične onima koji su živeli u Srbiji. Povodom aneksije Bosne i Hercegovine rodonačelnik srpskog liberalizma Vladimir Jovanović je 1908. pisao da se „stanovništvo Bosne, nekadašnje Srpske Kraljevine i Hercegovine, nekadašnje Velike Vojvodine Srpske, sastoji iz Srba, koji se jezikom, tradicijama, pesništvom, i literaturom, kao i fizičkim crtama, i naravno i običajima, ističu kao najčistiji predstavnici srpskog naroda". Ovome je dodao i da se upravo u BiH govori „visoko kultivisani srpski jezik”. ${ }^{\circ}$ Posle aneksije Bosne i Hercegovine Jovanović je smatrao da je Srbija pred izborom da usmeri „svoje energije i snage u odbranu svog prava na narodni opstanak" ili da i sama postane „,̌rrtva germanske najezde”." ${ }^{11}$ Tako posmatrano, narativ o Srbiji kao patronu i zaštitniku svih Srba u regionu dugotrajniji je od bilo koje političke strukture i od 19. veka pretrajava kao ključni nacionalni program i opravdanje za teritorijalnu ekspanziju.

Vladimir Jovanović je pisao da je 19. vek bio u znaku ujedinjenja „plemena koja govore jedan isti jezik" i kao ključno pitanje je postavljao: da li će 20. vek da ospori „veliku ideju, po kojoj ljudi jedne iste narodnosti imaju pravo na slobodan i nezavisan narodni život i razvitak?” Pozivajući se na nemački i italijanski slučaj, Jovanović nije imao odgovor na pitanje: šta kada bi svi balkanski narodi hteli da u maksimalističkim okvirima realizuju načelo koje je on tražio za Srbe. Takođe, Jovanović je očekivao od Evrope da zaustavi širenje Austrougarske ,i na druge delove Srpstva”, iako nije bilo jasno koje su sve teritorije bile uključene u navedenu formulaciju. Legitimaciju za teritorijalnu ekspanziju liberalni Jovanović, koji je slobodi pojedinca u svemu pretpostavljao slobodu nacionalnog kolektiviteta, pronalazio je u „potocima krvi” koje su Srbi „stolećima prolivali, braneći hrišćanstvo”. Osporavajući pravo Austrougarskoj na aneksiju Bosne i Hercegovine, utemeljitelj srpskog liberalizma je pisao da su „Bosanci i Hercegovci od prave srpske krvi, i potpuno svesni svog srpskog porekla”, zbog čega „prirodno teže” da se razvijaju „u duhu svoje narodnosti, verni svome jeziku i svojim tradicijama”, kao i da sami odlučuju „o svojoj sudbini”, zalažući se za do-

10

Vladimir Jovanović se školovao u Nemačkoj i u njegovim spisima su vidljivi nemački uticaji i nacional-romantičarski model. Vidi: B. Bešlin, Evropski uticaji na srpski liberalizam u 19. veku, Izdavačka knjižarnica Zorana Stojanovića, Novi Sad - Sremski Karlovci, 2005, str. 303, 511.

11

V. Jovanović, „Srpska prava i srpski interesi”, u: Izabrani spisi, Službeni glasnik, Beograd, 2011, str. 501. 
bijanje prava na politički „plebiscit”. Iako je zastupao ideju „samouprave” Bosne i Hercegovine, Vladimir Jovanović je podsećao i da se njena sudbina tiče „interesa celokupnog Srpstva, koje broji oko 10 miliona duša”. Zbog toga je aneksija BiH za njega značila „rastrzanje srpskog naroda, rastrzanje onakovo, kakovo bi bilo kad bi se jednome čoveku živome otkidali delovi jedan od drugoga”, što je bio primer organicističkog poimanja nacije u ideologiji srpskog nacionalizma. ${ }^{12}$ Naime, nacija se u srpskoj političkoj i društvenoj paradigmi do savremenosti ne percepira kao istorijski nova formacija, savremenih karakteristika, kao imaginativna konstrukcija heterogenog porekla, već kao večna, statična i nepromenjiva kategorija. Iza oznake nacije suštinski se nalazi pleme, zbog čega je nacija ostala determinisana rasom, kao „biološka, srodnička, vekovno stara, jednom rečju - organska”. ${ }^{13}$

\section{Bosanska banovina: Građanski liberali u monarhističkoj Jugoslaviji}

Prateći misao Vladimira Jovanovića, očito je da fragilna liberalna alternativa u Srbiji nije ostajala po strani od doktrinarnih nacionalističkih narativa, bivajući u njima tek nešto modernija i manje agresivna od radikalnih populista i konzervativaca Nikole Pašića okrenutih Rusiji u isključivoj misiji „nacionalnog oslobođenja i ujedinjenja”. ${ }^{14}$ Takva ideološka konstelacija bila je na tragu onoga što je istoričar i pravnik Slobodan Jovanović napisao: nacionalizam je u Srbiji ,jedina tradicija koja postoji, čvrsta i stamena”. ${ }^{15}$ Čak je i jedan od najliberalnijih srpskih političara druge polovine 19. veka Milan Piroćanac pisao da je "gubitkom Bosne i Hercegovine" na Berlinskom kongresu i sam opstanak Srbije bio doveden u pitanje. ${ }^{16}$ Ipak, od vremena stvaranja jedinstvene južnoslovenske države 1918. godine vodeća liberalna opcija, Demokratska stranka, koja je isprva bila zastupnik nacionalnog unitarizma i državnog centralizma, u vreme Šestojanuarske diktature, početkom 1930ih godina, evoluira ka federalističkoj platformi. U njihovim koncepcijama

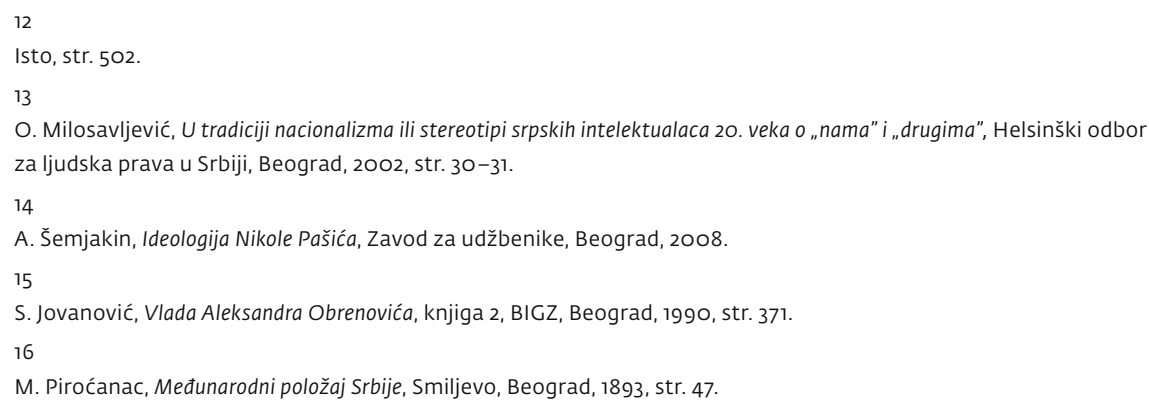


Bosna i Hercegovina od „srpske zemlje” i rezervoara za namirenje srpskih i hrvatskih velikodržavnih pretenzija s vremenom postaje ravnopravna jedinica u federalizovanoj Jugoslaviji.

Čelnik Demokratske stranke Ljuba Davidović je u „Pismu prijateljima u Bosni i Hercegovini” iz decembra 1939. kao reakciju na Sporazum Cvetković - Maček poručio da je Bosnu kroz istoriju „parčala zlokobna sudbina otimanja sa zapada, istoka i s juga o njenu dušu, otimanja sa svih strana o njenu zemlju, natopljenu krvlju... kao ni jedan kraj na Balkanu”. Davidović se obraćao svim stanovnicima Bosne i Hercegovine „u njenoj celosti u kojoj ih nikad nisam prestajao gledati”, podsećajući ljude „sve tri vere, kojim se god imenom nazivali" da su se Demokratska stranka i on zalagali da u federalizovanoj Jugoslaviji Bosna i Hercegovina bude zasebna jedinica, ravnopravna s onima koje bi konstituisale Srbija i Hrvatska. Posebna, bosanskohercegovačka multietnička i multikonfesionalna jedinica, prema Davidoviću, pacifikovala bi oštar antagonizam između srpskog i hrvatskog nacionalizma, ali bi i sprečila razgraničenje između Srba i Hrvata, jer tu granicu „nije moguće pametno postaviti”. Dokaz tome su i pregovori srpskih i hrvatskih predstavnika o sporazumu kojim je uspostavljena Banovina Hrvatska i koji je rezultirao „teškim i opasnim” komadanjem Bosne i Hercegovine. Davidović se zalagao i da se bosanskohercegovačkoj jedinici pripoji južna Dalmacija kako se ne bi „kidali i preprečavali prirodni putevi” i logične geografske celine. Ipak, sa žaljenjem je konstatovao da njegov predlog nije naišao na odobravanje ni kod Srba ni kod Hrvata, ali je poručivao da će neke buduće generacije uređenje zemlje postaviti na "razumne osnove”. ${ }^{17}$ Prema zamislima Davidovićeve Demokratske stranke, „Bosanci i Hercegovci, Srbi i Hrvati sve tri vere" u posebnoj, svojoj jedinici uživali bi široku samoupravu. ${ }^{18}$ To je, prema njegovoj oceni, neophodno jer je BiH bila diskriminisana, „bez bolnica, bez škola, bez zemlje u rukama onih koji od nje treba da žive”, bila je gladna uprkos rudnim, šumskim i ostalim prirodnim bogatstvima, dok je loša uprava, umesto poboljšavanja života ljudi, narode Bosne i Hercegovine huškala jedne na druge. Zbog toga je Davidović predlagao ujedinjenje ljudi u BiH i okretanje borbi protiv zla koje jednako pogađa sve njene narode. Na kraju obraćanja „prijateljima” u BiH Ljubomir Davidović je izražavao žaljenje što Demokratska stranka, zauzeta političkim borbama „u centru”, u Srbiji, nije razvila politički rad

17

B. Petranović, M. Zečević, Jugoslovenski federalizam - ideje i stvarnost, Prosveta - BIGZ, Beograd, 1987, str. 571.

18

Na predratni programski i politički stav Demokratske stranke prema BiH podsetio je partijski list Demokratija u oktobarskom broju iz 1945. ponovo afirmišući Pismo Ljube Davidovića za Bosnu i Hercegovinu iz 1939. godine. Vidi: Demokratija, br. 3, 11. oktobar 1945 . 
i partijsku infrastrukturu u Bosni i Hercegovini, iako u njoj ima, kako je napisao, „valjanih pristalica”. Završavajući svoje Pismo za BiH, pisano na njegov 76. rođendan, Davidović je poručivao da ako Bosna i Hercegovina već nije mogla postati ,jugoslovenska Švajcarska”, što joj je on želeo, nije smela biti ni ,jabuka razdora”. Na kraju je čelnik Demokratske stranke, osnovane u Sarajevu 1919. godine, poručio da se za interese Bosne i Hercegovine moraju izboriti samo njeni narodi, „ujedinjeni Bosanci i Hercegovci”. ${ }^{19}$

Nakon smrti svog predsednika i utemeljitelja Ljube Davidovića (1940) liberalna Demokratska stranka nije menjala odnos prema Bosni i Hercegovini. Njen novi predsednik Milan Grol je pred kraj Drugog svetskog rata u londonskoj emigraciji i dalje zastupao poznate stavove demokrata inaugurisane još 1932. o četiri federalne jedinice i BiH ravnopravnoj među njima, „oslobođenoj neposrednog uticaja Beograda i Zagreba”. Podsećao je Grol da bi u tom slučaju Bosna i Hercegovina bila „nacionalno neutralisana”, čime bi se sprečilo „odsečno” razgraničenje između Srba i Hrvata. Milan Grol, slično Ljubi Davidoviću, nije zaboravljao ni vekovnu bosansku državnost kao razlog za federalni status posebne jedinice $\mathrm{BiH}$. Ipak, podsećao je, time će „dva i po miliona Srba u Bosni i Hercegovini, Hrvatskoj i Dalmaciji” biti odvojeni od Srbije, što je bila „trećina srpskog naroda izdvojenog iz njegove matice”. Ali to je bio nužni kompromis s ciljem opstanka zajedničke države. Koliko je bio važan iskorak prema BiH građanskih liberala okupljenih oko Demokratske stranke, vidi se kada se uporedi njihov stav prema federalnoj državnosti Crne Gore i Makedonije. U slučaju Crne Gore demokrate i Grol lično pokazuju razumevanje u pogledu povratka istorijske državnosti, ali se ne mire sa nacionalnom posebnošću Crnogoraca, dok u slučaju Makedonije ne pristaju ni na nacionalnu ni na državnu emancipaciju, nudeći samo autonomiju u okvirima Srbije, jer, kako je rekao Grol, moravsko-vardarska dolina je morala ostati „nedeljiva”, a pitanje Makedonije bilo je za Srbiju pitanje „pluća”, odnosno vazduha i života. ${ }^{20}$

Čitava politička dinamika Kraljevine Jugoslavije svodila se na nacionalno pitanje i u prvom redu na srpsko-hrvatske dogovore, uz uvažavanje i zadovoljavanje slovenačkih zahteva. Pod teretom neuspeha integralnog jugoslovenstva kao ideologije Šestojanuarskog režima stvorena je 1939. Banovina Hrvatska, svojevrsni hrvatski corpus separatum, utemeljen na osnovu

19

B. Petranović, M. Zečević, Jugoslovenski federalizam - ideje i stvarnost, 1987, str. 572-573.

20

M. Grol, Iskušenja demokratije, Službeni glasnik, Beograd, 2005, str. 175-181. 
Sporazuma Cvetković - Maček. ${ }^{21}$ Usvajanjem tog sporazuma ideologija unitarizma i centralizma bila je ireverzibilno poražena, a srpsko pitanje otvoreno u novom obliku, zahtevom za srpskom teritorijalnom jedinicom, koja bi obuhvatila i „poslednjeg Srbina u Jugoslaviji”. ${ }^{22}$ Najistaknutiji zagovornik ovog usmerenja postaje u to vreme uticajni Srpski kulturni klub, koji je znatno iskoračio iz kulturnog i, pod predvodništvom desno-liberalnog istoričara i pravnika Slobodana Jovanovića, duboko zagazio u nacionalističko polje. Na tribinama Srpskog kulturnog kluba u drugoj polovini 1930-ih godina među najzapaženijim bila su i predavanja „O nacionalizovanju bosanskohercegovačkih muslimana” i „O muslimanskom problemu u Bosni i Hercegovini”. ${ }^{23}$ U SKK-u se otvoreno govorilo o komadanju Bosne i Hercegovine, rešenju „muslimanskog problema” u njoj, etničkom čišćenju Albanaca, asimilaciji Makedonaca... ${ }^{24}$ Srpski nacionalizam uspešno se uklapao u dominantne tokove evropske politike tridesetih godina 20. veka. Ostvarenje nekih ciljeva sprečila je agresija sila Osovine na Jugoslaviju i okupatorsko razbijanje države.

U to vreme su pažnje vredne i zamisli Mihaila Konstantinovića, levo-liberalnog profesora prava, ministra i kreatora Sporazuma o Banovini Hrvatskoj, koja je okrnjila granice i istorijsku teritoriju Bosne i Hercegovine. Njegove ideje su, ipak, podrazumevale i formiranje četvrte pokrajine. Osim hrvatske, srpske i slovenačke banovine, trebalo je da postoji i bosanskohercegovačka. Konstantinovićeva argumentacija je u velikoj meri bila podudarna sa polazištima Ljube Davidovića: Bosna i Hercegovina je bila potrebna kao tampon-zona između velike Srbije i velike Hrvatske, usled nemogućnosti razgraničenja Srba i Hrvata. Prema Konstantinovićevoj oceni, u procesima razgraničenja i stvaranja nacionalnih jedinica u Kraljevini Jugoslaviji poseban problem je činilo „postojanje Muslimana izmešanih sa Srbima i Hrvatima”. Takođe, veliki deo Srba iz BiH spremniji je bio da prihvati rešenje o četvrtoj, bosanskoj jedinici, nego da se nađe u okvirima Hrvatske banovine. Prema planovima Mihaila Konstantinovića, bosanska federalna jedinica bi obuhvatala teritoriju cele Vrbaske banovine, deo

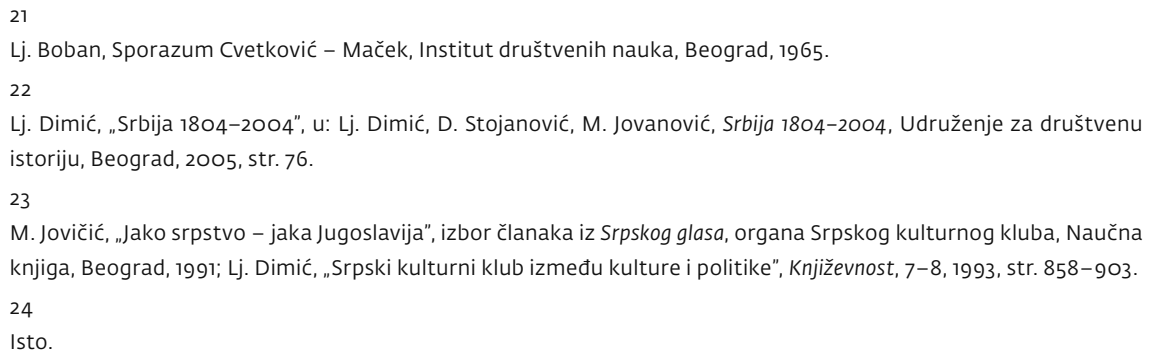


Drinske banovine koji se nalazio izvan granica nekadašnje Kraljevine Srbije i deo Zetske banovine koji nije obuhvatao granice nekadašnje Kraljevine Crne Gore. Tako zamišljena banovina imala bi nešto iznad dva miliona stanovnika i teritorijalno bi se poklapala sa istorijskim prostorom Bosne i Hercegovine, sa izuzetkom značajne teritorije koja je bila deo Primorske banovine i onih srezova koji su već uključeni u Banovinu Hrvatsku. ${ }^{25}$ Mihailo Konstantinović je u svojim planovima predlagao da Mostar, koji je bio u Primorskoj banovini, ipak pripadne četvrtoj, bosanskohercegovačkoj jedinici, jer bi to bila „težnja da Muslimani, zbog kojih se delimično ova pokrajina stvara, budu u jednoj pokrajini”. Slično kao i sa Mostarom, on je i Dubrovnik u budućoj bosanskoj banovini video i kao srpski i kao muslimanski interes. Ipak, dubrovačko pitanje je moralo biti mnogo kompleksnije i oko njega bi se hrvatski predstavnici znatno energičnije borili da ostane u njihovoj banovini, kako je procenjivao. Zamišljena, četvrta jedinica imala bi polovinu pravoslavnog življa, dok bi drugu polovinu činili katolici i muslimani. ${ }^{26}$ Do realizacije ovih planova nije došlo zbog početka Drugog svetskog rata i u Jugoslaviji.

Ipak, uprkos dobroj volji Mihaila Konstantinovića, Bosna i Hercegovina ne postoji kao subjekt, kao istorijska pokrajina, kao ravnopravni učesnik u raspravama o budućem uređenju države. Naposletku, metod kojim su liberalni intelektualci i vodeći pravni eksperti međuratne Jugoslavije: Mihailo Konstantinović, Đorđe Ilić i Đorđe Tasić konstruisali Banovinu Hrvatsku, od delova $\mathrm{BiH}$, kao i način na koji su postupali sa njenom teritorijom u projektovanju buduće srpske banovine, svedoči da je Bosna i Hercegovina teško mogla opstati kao ravnopravna i u svojim istorijskim granicama.

\section{Povratak izvorima: Građanski liberali i BiH u epohi federativne Jugoslavije}

U toku Drugog svetskog rata, koji je na jugoslovenskom prostoru podrazumevao oslobodilačku borbu i socijalističku revoluciju (1941-1945), izvršen je proces konstituisanja federativne Jugoslavije kao složene zajednice ravnopravnih naroda, čiji su se prelomni i završni akti odigrali krajem 1943. i u leto 1945. na Drugom i Trećem zasedanju AVNOJ-a. Od početka ustanka,

\footnotetext{
25

M. Konstantinović, Politika sporazuma. Dnevničke beleške 1939-1941. Londonske beleške 1944-1945, Mir, Novi Sad, 1998, str. 516-517.

26

Isto, str. 518-519.
} 
a i ranije, prevladavalo je stanovište u rukovodstvu KPJ da bi Bosna i Hercegovina trebalo da ima autonomiju, ali se nikada nije preciziralo u kom obliku bi se takva zamisao realizovala. Optimalno rešenje je predviđalo da se konstituiše kao federalna država, odnosno ravnopravna članica federativne Jugoslavije u nastanku. Na insistiranje Pokrajinskog komiteta Komunističke partije BiH, ali i Tita lično, prevagnuo je stav da se BiH kao istorijski utemeljena geografska i ekonomska celina, sa specifičnom nacionalnom i konfesionalnom strukturom, izgradi kao ravnopravna članica federativne Jugoslavije. ${ }^{27}$

Kada su u vrhu KPJ-a rešena temeljna pitanja bosanskohercegovačke državnosti i pozicije u federalističkoj konstelaciji koja se stvarala, sazvano je Zemaljsko antifašističko vijeće narodnog oslobođenja BiH, i to samo nekoliko dana pred Drugo zasedanje AVNOJ-a, kako bi legitimisalo odluke partijskog vrha. Konstitutivno zasedanje ZAVNOBiH-a održano je u Mrkonjić-Gradu 26. i 27. novembra 1943. godine. U centralnom dokumentu ovog istorijskog zasedanja ističe se da Bosna i Hercegovina „nije ni srpska, ni hrvatska, ni muslimanska, nego i srpska i muslimanska i hrvatska" i da ta tri naroda „zbratimljena” tvore slobodnu BiH u kojoj će biti garantovana „puna ravnopravnost i jednakost svih Srba, Muslimana i Hrvata”. Takva Bosna i Hercegovina sa tri konstitutivna naroda „učestvovaće ravnopravno sa ostalim našim narodima u izgradnji narodne demokratske federativne Jugoslavije". ${ }^{28}$

Međutim, ovakvo rešenje, osim kod srpskih nacionalista i poraženog kvislinštva, nailazilo je na kritike i među buržoaskim, liberalnim krugovima. Jedan od najeksponiranijih progresivnih političara međuratne Jugoslavije, levo-liberalno opredeljeni vođa zemljoradnika i profesor prava Dragoljub Jovanović govorio je nakon uvođenja jugoslovenskog federalizma pod komunistima da su u njemu Srbi majorizovani. Osim što je crnogorsku naciju smatrao „šalom” i fikcijom i zalagao se za pripajanje Republike Crne Gore Srbiji, Bosnu i Hercegovinu je smatrao još težim slučajem. Srbi iz BiH su, tvrdio je Jovanović, dolazili kod njega i plakali zbog svog, navodno, teškog položaja unutar federalne države BiH. Zbog toga su se, smatrao je Jovanović, oni masovno selili u Srbiju, a posebno tragičnim je isticao činjenicu da su u popisima u socijalističkoj Jugoslaviji Srbi „izgubili” relativnu većinu u

27

R. Hurem, Bosna i Hercegovina u Drugom svjetskom ratu 1941-1945, University Press, Sarajevo, 2016, str. 345-352; R. Končar, Stvaranje federacije, Centar za političke studije i marksističko obrazovanje, Novi Sad, 1983, str. $20-21$.

28

S. Nešović, B. Petranović, AVNOJ i revolucija. Tematska zbirka dokumenata 1941-1945, Narodna knjiga, Beograd, 1983, str. 434. 
Bosni i Hercegovini. Muslimansku naciju Dragoljub Jovanović je smatrao „apsurdom” i pokušajem da se pobegne od Beograda i Zagreba. Kao veoma negativnu karakteristiku, tvrdio je da republičko vođstvo u $\mathrm{BiH}$,brutalno progoni emisare” koji u Bosnu dolaze iz Srbije i Hrvatske.29 Ipak, pred kraj života, u prepisci s Desimirom Tošićem, Dragoljub Jovanović je, govoreći o Bosni i Hercegovini i Crnoj Gori, priznavao da „nijedna od tih pokrajina neće da bude Srbija”, zbog čega je federaciju koju su stvorili komunisti posle 1945. smatrao kao najbolje rešenje.30

Jedan od najliberalnijih srpskih političkih emigranata, koji je u izgnanstvu blisko sarađivao is Adilom Zulfikarpašićem, glavni urednik liberalne Naše reči Desimir Tošić se 1971. našao, sticajem okolnosti, na bliskim pozicijama sa predsednikom Skupštine Srbije Dražom Markovićem, predvodnikom konzervativne struje u srpskoj partiji. Spojilo ih je gledanje na tzv. srpsko pitanje i reformu federacije, a Tošić je čak hvalio Markovića zbog pružanja otpora široj autonomiji pokrajina. Tako Desimir Tošić u kontekstu ustavnih amandmana iz 1971. piše da „nema nikakvog ozbiljnog smisla govoriti o državnosti Bosne i Hercegovine”, posebno kada se uporedi sa drugim republikama, poput Hrvatske. Položaj Srba u Jugoslaviji posle decentralizacije Tošić je smatrao „u potpunosti neprihvatljivim”, ali i „istorijski i praktično-politički nemogućim”. Srbi su, prema njegovoj oceni, ustavnim promenama bili „raščerečeni” i u težem položaju nego pre Balkanskih ratova 1912. godine. Zbog toga se zalagao za promenu unutrašnjih granica Jugoslavije kako bi Srbi, ako već ne mogu da zadrže više od „devet desetina” svog življa u matičnoj republici, kao Slovenci i Makedonci, prekomponovali državu da po ugledu na Hrvate, unutar proširene Srbije, zadrže „osam desetina svog naroda”. Ako se ne bi išlo za tim rešenjem, koje bi podrazumevalo pripajanje velikih delova Bosne i Hercegovine Srbiji, „izvršila bi se potpuna diskriminacija srpskog naroda”, pisao je Tošić u londonskoj Našoj reči u maju 1971. godine. ${ }^{31}$

I u socijalističkoj Jugoslaviji, nacionalističko-liberalna opozicija i disidenti, poput emigracije, otvoreno negiraju granice i državnost Bosne i Hercegovine. Na tribini Pravnog fakulteta u Beogradu u martu 1971. liberalni filozof Mihailo Đurić je imao zapažen i u Srbiji široko rasprostranjen istup. Goruće

D. Jovanović, Ljudi, ljudi..., knjige I-II, izdanje autorovo, Beograd, 1973-1975.

30

M. Lakićević, Desimir Tošić: između ekstrema, Akademska knjiga, Novi Sad, 2020, str. 490.

31

D. Tošić, Stvarnost protiv zabluda. Srpsko nacionalno pitanje, S. Mašić, Beograd, 1997, str. 55-69; M. Lakićević, Desimir Tošić: između ekstrema, str. 396. 
pitanje za njega je bilo mesto i položaj Srbije i srpskog naroda u novoj konstitutivnoj konstelaciji: „Treba biti načisto s tim da je Jugoslavija već danas gotovo samo geografski pojam, budući da se na njenom tlu, ili tačnije, na njenim razvalinama... uspostavlja nekoliko samostalnih, nezavisnih čak i međusobno suprotstavljenih nacionalnih država...” Međutim, nastavljao je Đurić, „, ne pada mi ni na kraj pameti da se zalažem za spasavanje po svaku cenu nečeg što se ne može spasiti i što u ovakvom vidu ili prividu nije ni vredelo stvarati”. Predstavljajući nacionalno i republičko razgraničavanje kao nametnuto, Đurić je smatrao da je „za srpski narod u ovom času od najveće važnosti pitanje njegovog identiteta i integriteta, dakle, pitanje njegovog političkog, njegovog državno-pravnog objedinjavanja”.32 Granice svih jugoslovenskih republika, po njemu, imaju samo „uslovno značenje”, a posebno granice SR Srbije, koje nisu ,nikakve ni nacionalne ni istorijske granice srpskog naroda”, a njihova „,neprikladnost, proizvoljnost i neodrživost" postaju sasvim očigledne kada se posmatraju kao granice nacionalnih država. Nezadovoljstvo tim granicama Đurić je izrazio stavom da ni za jednu republiku, sem Slovenije, one nisu odgovarajuće, a „pogotovo ne za Srbiju”. Iznoseći podatak da izvan tzv. uže Srbije živi čak 40\% Srba, on se zapitao ima li srpski narod pravo da bude ravnodušan prema „svojim mnogobrojnim delovima izvan sadašnjih granica SR Srbije”. Srpski narod, nastavljao je Mihailo Đurić, nalazio se i do tada u neravnopravnom položaju, a usvajanjem promena Ustava njihov će se status pogoršati, jer izvan Srbije Srbi žive u još „četiri od pet republika”, ali ni u jednoj od tih preostalih republika „ne žive svojski”. Navedenu tezu je potkrepio tvrdnjom da u Bosni i Hercegovini, iako čini „,većinu stanovništva”, srpski narod nije imao ni pravo na „svoje ćirilično pismo”, što je imalo za cilj izdvajanje iz celine nacionalne kulture, tj. razbijanje jedinstvenog kulturno-duhovnog prostora. ${ }^{33}$ Paradigmatično je da se i među liberalnom inteligencijom, kako u zemlji tako i u emigraciji, početkom 1970-ih godina ponovo javlja organicistički diskurs 19. veka o tzv. srpskom prostoru kao homogenom i jedinstvenom „biću”, koje se decentralizacijom i demokratizacijom Jugoslavije „rasparčava i komada”. Reč je o dubokim kontinuitetima ideologije srpskog nacionalizma, koja je najozbiljniji idejno-politički izazov dobila upravo u tom periodu. 


\section{Borba s kontinuitetima: Komunistički liberali Marka Nikezića prema Bosni i Hercegovini}

Nasuprot ambivalentnim pozicijama građanskih liberala stajali su srpski komunistički liberali. Od kraja novembra 1968. u Srbiji su ključne političke pozicije zauzimali dotadašnji šef savezne diplomatije Marko Nikezić i njegova najbliža saradnica Latinka Perović kao predsednik i sekretar Centralnog komiteta Saveza komunista Srbije. Kada je reč o Bosni i Hercegovini, odnos srpskog reformskog rukovodstva prema središnjoj jugoslovenskoj republici je najbolje i najcelovitije formulisan u sarajevskom govoru Marka Nikezića iz 1970. godine. Srpski narod, smatrao je on, nalazi vlastiti identitet i punu afirmaciju kako u Jugoslaviji i Srbiji tako i u Bosni i Hercegovini i Hrvatskoj, republikama u kojima Srbi žive ravnopravno sa drugim narodima. Upravo zbog toga bi bilo kakva pretenzija ili samo intencija Republike Srbije za staranjem o svim Srbima u Jugoslaviji bio „čist nacionalizam”, poručivao je prvi čovek srpskih (komunističkih) liberala. Sarajevski govor Marka Nikezića bio je dobra prilika da zvanična Srbija jasno iskaže svoje namere u pogledu budućnosti i karaktera centralne jugoslovenske republike, u kojoj zajedno žive Hrvati, Srbi i Muslimani, „ne odričući se svog nacionalnog identiteta i kulture, već naprotiv, potvrđujući ih u punoj slobodi”, što je „osnov jedinstva i stabilnosti Bosne i Hercegovine....”34 Pozivajući komuniste sva tri bosanskohercegovačka naroda na borbu protiv nacionalističkih koncepcija i ponašanja unutar svog naroda, Marko Nikezić je posebno neprihvatljivim smatrao svaki pokušaj uplitanja Beograda ili Zagreba i njihovog tutorstva nad bosanskim Srbima ili Hrvatima, što će njegovo rukovodstvo smatrati ,jednom od svojih prvih obaveza”. Time je Srbima u Bosni poslata jasna poruka da puteve rešavanja životnih pitanja moraju tražiti u dogovoru s narodima s kojima žive, ali je poručeno i hrvatskom rukovodstvu da nacionalistički talas koji je zahvatio ovu republiku ne preliva na susednu BiH. Nacionalistima unutar Srbije Nikezić je sarajevskim govorom poručio da reformsko rukovodstvo srpskih komunista Republiku Srbiju u svojim ustavnim granicama doživljava kao konačan, a ne privremen okvir, koji će biti prvom prilikom zamenjen novim granicama između jugoslovenskih federalnih država. Umesto imperijalnih težnji i intencije za patronatom nad Srbima izvan Srbije, Nikezićevo vođstvo je ponudilo novu paradigmu, verujući da „Srbija treba dublje da porine sama u sebe, da se zabavi sopstvenim razvojem, da na tome mobiliše svoje narasle snage... da se oslobađa pijemontske uloge" ${ }^{35}$ 
Pozivajući se u dijalogu rukovodstava Srbije i Bosne i Hercegovine iz septembra 1971. na svoj sarajevski govor iz prethodne godine, ali i na stav koji je Latinka Perović saopštila kulturnim radnicima da su „Srbi van Srbije kod svoje kuće i slobodni i ravnopravni u drugim republikama”, odnosno da nisu „porobljeni delovi srpskog naroda”, Marko Nikezić je naglasio da se mnogi ljudi ne slažu s tim. Rekao je i da mu je došla u posetu delegacija Srba iz Like, čiji predstavnici su mu saopštili da su ljudi u njihovom kraju plakali zbog njegove sarajevske izjave da ,nismo staraoci Srbima van Srbije”. Nacionalizam je u Srbiji kontinuitet i „ja vidim”, rekao je Marko Nikezić, „smisao naše političke akcije u borbi sa tim kontinuitetima”. ${ }^{6}$

Marko Nikezić je smatrao da je već samo postojanje Bosne i Hercegovine prepreka nacionalističkoj identifikaciji republičkih i nacionalnih interesa. Takođe, prema njegovoj oceni, samostalna politika bosanskohercegovačkog rukovodstva utoliko više potvrđuje ovaj pozitivan efekat Bosne na čitavu Jugoslaviju. Zbog svega rečenog, smatrao je Nikezić, „oni koji su zainteresovani za jedinstvo Jugoslavije moraju biti zainteresovani i za jedinstvo u Bosni i Hercegovini”. Zbog toga je važno voditi računa o tome kakve su konsekvence poteza koje „,učemo po interese drugog”, jer brinuti o drugome u Jugoslaviji, prema Nikezićevoj oceni, značilo je voditi računa o sopstvenom interesu. . $^{37}$

Politički vrh Srbije, poručivala je i Latinka Perović, insistiraće iznad svega na „učvršćivanju Bosne i Hercegovine, a to znači na njenoj daljoj afirmaciji unutar Jugoslavije kao ravnopravne republike, kao ravnopravne političke organizacije”. Eventualni unutrašnji konflikti i nestabilnost u BiH u pogledu međunacionalnih odnosa imali bi, prema njenoj oceni, dalekosežne posledice za jedinstvo i mir u čitavoj Jugoslaviji. Iako je stav zvanične Srbije bio jasan, u Srbiji su postojali pojedinci i organizacije koji su odudarali od takve politike, rekla je ona, jer srpski nacionalizam i nije imao drugu politiku sem funkcionalizacije Srba izvan Srbije. A ako se jedna politika angažuje na toj osnovi, onda su pretenzije prema BiH i logične i očekivane, a za srpske liberale je ključno pitanje bilo kako to onemogućiti. Na konkretnom političkom pitanju, smatrala je ona, važno je pokazati da BiH nije nikakva „surogat republika”,

L. Perović, Zatvaranje kruga, Svjetlost, Sarajevo, 1991, str. 165

36

Arhiv Srbije (AS), Fond SKS - Centralni komitet, Konsultativni sastanci, saradnja sa CK drugih republika, br. kutije 95. Stenografske beleške razgovora delegacija CK SK Srbije i CK Bosne i Hercegovine u Beogradu 27. septembra 1971. 
jer je upravo to najbolja odbrana od „paternalističkih tendencija iz Srbije”. ${ }^{8}$ Latinka Perović je u razgovorima s institucijama koje su zagovarale nacionalističku platformu, pre svega sa Srpskom književnom zadrugom, poručila da se kultura srpskog naroda ne poklapa sa državnim granicama SR Srbije, ali da ta činjenica nije mogla da se posmatra kao razlog promene državnog i društvenog uređenja SFRJ. Takođe im je poručila da liberalno rukovodstvo delove srpskog naroda koji žive u BiH ne smatra za pastorčad, već su oni „slobodni delovi u okviru jugoslovenske socijalističke zajednice sa istim društvenim statusom" i da nikakva pokroviteljska briga Srbije nije potrebna. To je, prema njenoj oceni, jedina politika koja bi bila u stanju da razvije program stvarnog suživota, komuniciranja uz poštovanje ravnopravnosti i koja bi suzbijala velikosrpski nacionalizam i njegove pretenzije. Ako bi se, na primer, problem Srba, smatrala je Latinka Perović, svuda učinio spornim od Kosova do Hrvatske, to bi značilo prevagu nacionalizma i u Srbiji. A bilo koje nacionalno organizovanje i homogenizacija u Bosni je „zaista jedan slom" za BiH, ali i za Jugoslaviju, smatrala je. ${ }^{39}$

Gotovost na destrukciju federacije u ime nacionalnih prava po Nikeziću je podrazumevalo postavljanje srpskog pitanja na dnevni red, pozicioniranje Srbije kao opozicije federaciji i, što je još važnije, otvaranje pitanja Bosne i Hercegovine i Hrvatske, u kojima je živeo veliki broj Srba. Tu vrstu polaganja prava na centralnu jugoslovensku republiku - Bosnu i Hercegovinu - prvi čovek srpskih komunista identifikovao je i kod hrvatskih nacionalista, zaključujući da kad „počnu da se svađaju srpski i hrvatski nacionalisti oko Bosne, to je razbijanje Jugoslavije”. ${ }^{\circ 0}$ Covoreći o srpsko-hrvatskim odnosima, Latinka Perović je zaključivala da to ne može biti centralno pitanje u Jugoslaviji, jer je takva teza mogla da odgovara samo srpskim nacionalistima: „najpre sporazum sa Hrvatima na račun svih ostalih”, a pre svega dogovor o podeli Bosne i Hercegovine, a potom bi se sa Hrvatima stvari rešavale „na bazi odnosa snaga”, u međusobnom obračunu, anticipirala je ona dve decenije unapred tok jugoslovenske krize. ${ }^{41}$

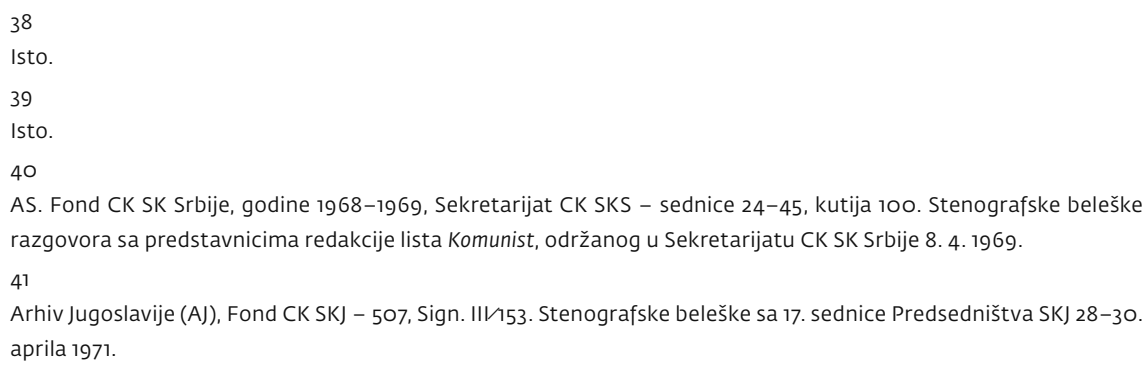




\section{Bosna i Hercegovina kao indikator: Ima li liberalizma u Srbiji?}

Po dolasku srpskih komunističkih liberala Marka Nikezića na ključne pozicije u Srbiji redefinisana je nacionalna politika, prevashodno kao izraz odnosa prema susedima, posebno onima unutar čijih granica se našao znatniji broj Srba u vreme kada su jugoslovenske republike dobijale veći stepen samostalnosti, postajući i suštinski nacionalne države konstitutivnih naroda. Uz dva tradicionalna pojavna oblika nacionalne politike u Srbiji: sve slabijeg jugoslovenskog centralizma i sve snažnijeg (pan)srpstva, Nikezićevi reformisti su inaugurisali i treću političku platformu kao alternativu postojećim. Reč je o programskoj novini u čijem fundamentu se nalazio projekat decentralizacije, koju su oni usvojili i razumeli kao šansu za izgradnju Srbije kao moderne države i pluralističkog društva, što je bila kvintesencija programa srpskih (komunističkih) liberala. Istoričarka Olga Popović Obradović je smatrala da srpsko rukovodstvo od 1969. do 1972. „uprkos komunističkoj ideološkoj provenijenciji, opravdano može poneti liberalni predznak", jer doktrinarnog liberalizma u istoriji Srbije nije bilo. Prema njenoj oceni, sva fundamentalna pitanja u istoriji Srbije 19. i 20. veka svodiva su na dva osnovna pitanja: prvo je odnos prema vrednostima modernog doba ili prema modernizaciji, što se može okarakterisati i odnosom prema Zapadu, a drugo je nacionalni program Srbije kao izraz njenog odnosa prema susedima, odnosno vlastitim velikodržavnim pretenzijama. Kada je o tome reč, srpski komunistički liberali su, pisala je, stajali u izrazitom raskoraku sa srpskim nacionalizmom i bili su njegovi „neumoljivi protivnici”. ${ }^{22}$ Utoliko su oni bili nesporno dosledniji liberali od onih građanskih, koji su u realnosti najčešće bili tek umerenije opcije velikosrpskih nacionalista.

Kada je reč o odnosu prema Bosni i Hercegovini, od rodonačelnika srpskog liberalizma u 19. veku Vladimira Jovanovića, koji ju je video kao središte zamišljene Srbije, a njene stanovnike kao nepodeljene Srbe, preko Milana Piroćanca, koji je opstanak Srbije uslovljavao zaposedanjem BiH, tek stvaranjem Jugoslavije evoluiraće stavovi liberalnih političara prema ovom središnjem delu zajedničke države. Kopernikanski obrt načinjen je federalističkim koncepcijama Demokratske stranke i zavidnim stepenom benevolentnosti njenih čelnika Ljube Davidovića i Milana Grola prema 
Bosni i Hercegovini i njenim narodima. Uprkos krnjenju njenih istorijskih teritorija, neće BiH mnogo drugačije videti ni Mihailo Konstantinović, tvorac Sporazuma Cvetković - Maček. Ono što je zajedničko navedenim konceptima, uprkos širini koju su srpski buržoaski (građanski) liberali međuratnog perioda pokazivali prema Bosni i Hercegovini, jeste činjenica da ona nije tretirana kao politički subjekt, već kao objekat kojem se ravnopravnost daruje i to uglavnom u funkciji tampon-zone između srpsko-hrvatskog razgraničenja. Nakon što je u federalizovanoj Jugoslaviji Bosna i Hercegovina zauzela mesto federalne države, ravnopravne s ostalima, srpski građanski liberalizam se vraća korenima i iznova negira njenu državnost, istorijske granice, bošnjačku (muslimansku) naciju i uopšte političku egzistenciju BiH.

Nasuprot njima, liberalni deo unutar jedinstvenog, ali ne i monolitnog Saveza komunista Srbije odgovarao je negacijom konzervativno-nacionalističke paradigme, strategijom oslobađanja od misije da je Srbija „čuvar” Jugoslavije od svih ostalih i nasuprot ostalim narodima, politikom čistih računa, okretanja Srbije sebi, fokusiranjem na unutrašnji ekonomski i kulturni razvoj i uopšte otkrivanjem srpskog identiteta s one strane nacionalizma, centralizma, nasilja i velikodržavlja. Time su Nikezićevi liberali konstruisali program, ne samo izvan nego i nasuprot decenijama ukorenjenoj ekspanzivnoj, nacionalističkoj tradiciji u Srbiji, koja je, pre svega, Bosnu i Hercegovinu videla kao jezgro velikodržavnog projekta. ${ }^{43}$ Raskidajući sa svim ključnim elementima ideologije srpskog nacionalizma, posmatrajući BiH kao ravnopravnu federalnu državu unutar Jugoslavije, odbacujući bilo kakve dogovore sa hrvatskim rukovodstvom koji bi nužno išli na račun BiH, ali i snažno odbacujući bilo kakav patronat nad Srbima izvan Srbije, Nikezićevi liberali su načinili suštinski diskontinuitet s ključnim tradicionalnim idejnim postavkama srpskih elita od 19. veka, ponudivši novu filozofiju nacionalne politike. Njihovom smenom 1972. Srbija se vraća konzervativnim i nacionalističkim kontinuitetima, koji će vrhunac doživeti početkom 1990-ih konsenzualnim težnjama za destrukcijom međunarodno priznate Republike Bosne i Hercegovine. ${ }^{44}$ 


\section{Izvori i literatura}

Arhiv Jugoslavije, Fond CK SKJ

Arhiv Republike Slovenije, Fond br. 1945, Zbirka Srbski liberalizem

Arhiv Srbije, Fond SKS - Centralni komitet

Biserko, S. (2006), Bosna i Hercegovina - jezgro velikosrpskog projekta, Helsinški odbor za ljudska prava u Srbiji, Beograd

Bešlin, B. (2005), Evropski uticaji na srpski liberalizam u 19. veku, Izdavačka knjižarnica Zorana Stojanovića, Novi Sad - Sremski Karlovci

Boban, Lj. (1965), Sporazum Cvetković - Maček, Institut društvenih nauka, Beograd

Demokratija, br. 3, 11. oktobar 1945.

Dimić, Lj. (1993), „Srpski kulturni klub između kulture i politike”, Književnost, 7-8, str. 858-903.

Dimić, Lj. (1996), Kulturna politika u Kraljevini Jugoslaviji 1918-1941, tom 1, Stubovi kulture, Beograd

Dimić, Lj. (2005), „Srbija 1804-2004”, u: Dimić, Lj., D. Stojanović, M. Jovanović, Srbija 1804-2004., Udruženje za društvenu istoriju, Beograd

Đurić, M. (1971), „Smišljene smutnje”, Anali Pravnog fakulteta u Beogradu, 3 , str. 230-233.

Đurić, M. (1997), Izazov nihilizma - iskustvo razlike, Službeni list SRJ, Beograd

Đorđević, D. (1997), „Milovan Milovanović”, u: Portreti iz novije srpske istorije, BICZ, Beograd

Ekmečić, M. (1997), „Karakteristike Berlinskog kongresa 1878. godine”, u: Radovi iz istorije Bosne i Hercegovine 19. veka, BICZ, Beograd

Grol, M. (2005), Iskušenja demokratije, Službeni glasnik, Beograd

Hejvud, E. (2005), Političke ideologije, Zavod za udžbenike i nastavna sredstva, Beograd

Hurem, R. (2016), Bosna i Hercegovina u Drugom svjetskom ratu 1941-1945., University Press, Sarajevo

Jovanović, D. (1973-1975), Ljudi, ljudi..., knjige I-II, izdanje autorovo, Beograd Jovanović, S. (1990), Vlada Aleksandra Obrenovića, knjiga 2, BICZ, Beograd

Jovanović, V. (2011), „Srpska prava i srpski interesi”, u: Izabrani spisi, Službeni glasnik, Beograd

Jovičić, M. (1991), ,Jako srpstvo - jaka Jugoslavija”, izbor članaka iz Srpskog glasa, organa Srpskog kulturnog kluba, Naučna knjiga, Beograd

Končar, R. (1983), Stvaranje federacije, Centar za političke studije i marksističko obrazovanje, Novi Sad

Konstantinović, M. (1998), Politika sporazuma. Dnevničke beleške 1939-1941. Londonske beleške 1944-1945., Mir, Novi Sad

Lakićević, M. (2020), Desimir Tošić: između ekstrema, Akademska knjiga, Novi Sad 
Ljušić, R. (2002), Istorija srpske državnosti, Ogranak SANU, Novi Sad Milosavljević, O. (2002), U tradiciji nacionalizma ili stereotipi srpskih intelektualaca 20. veka 0 „nama” $i$, drugima”, Helsinški odbor za ljudska prava u Srbiji, Beograd Mimica, A., ur. (2002), Druga Srbija - deset godina posle: 1992-2002., Helsinški odbor za ljudska prava u Srbiji, Beograd

Mitrović, A. (1981), Prodor na Balkan. Srbija u planovima Austro-Ugarske i Nemačke 1908-1918., Nolit, Beograd

Nešović, S., B. Petranović (1983), AVNOJ i revolucija, tematska zbirka dokumenata 1941-1945., Narodna knjiga, Beograd

Perović, L. (1991), Zatvaranje kruga, Svjetlost, Sarajevo

Perović, L. (2006), „Mogućnosti i ograničenja modernizacije”, u: Između anarhije i autokratije, Helsinški odbor za ljudska prava u Srbiji, Beograd

Petranović, B., M. Zečević (1987), Jugoslovenski federalizam - ideje i stvarnost, Prosveta - BICZ, Beograd

Piroćanac, M. (1893), Međunarodni položaj Srbije, Smiljevo, Beograd

Popov, Č., ur. (1994), Istorija srpskog naroda, Knjiga VI, tom 1, Srpska književna zadruga, Beograd

Popović Obradović, O. (2003), „Srpska i(li) srbijanska politika”, u: Prelomna 72. Uzroci i posledice pada srpskih (komunističkih) liberala, Ekonomist magazin, Beograd

Popović Obradović, O. (2008), Kakva ili kolika država. Ogledi o političkoj i društvenoj istoriji Srbije 19-21. veka, prir. Latinka Perović, Helsinški odbor za ljudska prava u Srbiji, Beograd

Šemjakin, A. (2008), Ideologija Nikole Pašića, Zavod za udžbenike, Beograd Tošić, D. (1997), Stvarnost protiv zabluda. Srpsko nacionalno pitanje, S. Mašić, Beograd 


\section{Bourgeois and Communist Liberals in Serbia about Bosnia and Herzegovina ${ }^{45}$}
Abstract: The paper starts from the tuals expressed dissatisfaction fact that in the territorial aspirati- ons of Serbian nationalism in the 19th and 2oth centuries, Bosnia \& Herzegovina was at the center of expansion. Contrary to the domi- nant tendencies of the nationalist matrix, the minority liberal alter- native in Serbia, although a part of the so-called great (national) narra- tive, showed considerably more sen- sitivity to the differences of $\mathrm{B} \& \mathrm{H}$, expressing the need to establish it as a separate unit in the Yugo- slav federalism. However, when the socialist government in Tito's Yugoslavia enabled the statehood and essential equality of Bosnia \& Herzegovina, most liberal intellec- with such a constellation. Bosnia \& Herzegovina's statehood, like its borders, was perceived as temporary and provisional. The only political structure in Serbia that showed full understanding for the essential statehood of $\mathrm{B} \& \mathrm{H}$ and that made a complete discontinuity with the attitudes of Serbian elites towar- ds Bosnia \& Herzegovina were the communist liberals, Marko Nike- zic's reform leadership in Serbia in the late 196os and early 1970s.
Keywords: Yugoslavia, Serbia, Bosnia \& Herzegovina, nationalism, bouorgeois liberals, communist liberals, federalism. 